\title{
The End of Carnivalism, or The Making of the Corpus Lucianeum
}

\section{El fin del carnavalismo o la creación del Corpus Lucianeum}

\author{
Markus Hafner ${ }^{1}$ \\ University of North Carolina at Chapel Hill (EEUU)
}

Recibido: 15-02-19

Aprobado: 06-03-19

\begin{abstract}
In a key passage for the understanding of Lucian's work, the Fisherman 2527, the philosopher Diogenes of Sinope complains that Parrhesiades, a Lucianlike authorial figure, mocks philosophers not within the fixed boundaries of a carnivalesque festival, as Old Comedy used to do, and to which Lucian's work is otherwise highly indebted, but by means of his constantly published writings. This statement is even more relevant, since the Fisherman belongs to a group of texts which show clear cross-references to other writings within the corpus (such as Essays in Portraiture Defended, Apology, and The Runaways). By creating indirect authorial commentaries and intratextual references throughout his œuvre - a hidden (auto)biobibliography, as it were-, Lucian thus reinforces the idea of an organic literary work and the coherency of his corpus which is - notwithstanding its thematic variatio - well-publicized and far away from carnivalesque exceptionality. In this way, the aesthetics of perpetual transgression is in a unique way related to the construction of authorial self-referentiality in Lucian's satires.
\end{abstract}

Key-words: carnivalism, publication, intratextuality, biobibliography, Pseudo-Lucianea, authorial fictions.

\footnotetext{
${ }^{1}$ (markus.hafner@klassphil.uni-muenchen.de) Markus Hafner gained his doctorate in Classics at LMU Munich in 2016 and taught courses in Latin and Greek at various levels at LMU Munich (2013-2016), Heidelberg University (2017/8), and the Humboldt University of Berlin (2018). His scholarship focuses on Lucian the Satirist, on whose works he has published two commentaries (both published in 2017). In his articles, which have appeared in journals and edited volumes, he considers the various techniques of persuasive rhetoric in Imperial Greek Literature. At present, he is working on a book-length project on conceptions of collaborative authorship in Late Archaic and Classical Greek literature. He is conducting this research project as an Alexander von Humboldt Fellow at the UNC at Chapel Hill.
} 


\section{Resumen}

En un pasaje clave para entender la obra de Luciano, Piscator 25-27, el filósofo Diógenes de Sinope se queja de que Parresíades, una figura de autoría parecida a Luciano, no se burla de los filósofos dentro de los límites carnavalescos del festival, como lo hacía la Comedia Vieja, a la que tanto debe la obra de Luciano, sino mediante constantes publicaciones de escritos. Esta afirmación adquiere aún mayor importancia por el hecho de que el Piscator pertenece a un grupo de textos que muestra evidentes referencias cruzadas a otros escritos del corpus (como Pro imaginibus, Apologia o Fugitivi). Al crear indirectamente comentarios de autoría y referencias intertextuales a través de su obra 'multitemática' - por así decir, una (auto)bibliobiografía escondida -, Luciano refuerza la idea de una obra literaria orgánica y un corpus coherente que se encuentra - a pesar de la variatio temática - bien divulgado y lejos de la excepcionalidad carnavalesca. Así, la estética de la trasgresión perpetua está relacionada de manera única con la construcción de la auto-referencialidad como autor en las sátiras de Luciano.

Palabras-clave: carnavalismo, publicación, intratextualidad, biobibliografía, Pseudo-Lucianea, ficciones autoriales.

\section{Introduction: Lucian and the end of carnivalism ${ }^{2}$}

In a programmatic passage of his dialogue The Dead Come to Life, or The Fisherman (Revivescentes sive Piscator), the satirist Lucian of Samosata $\left(2^{\text {nd }} \mathrm{c} . \mathrm{CE}\right)$ explicitly makes one of his numerous fictitious characters express his view concerning the making and structure of the Lucianic corpus. ${ }^{3}$ Before commenting further on this Lucianic technique, however, I shall briefly offer a summary of The Fisherman's plot. Within the scenery and topography of Classical Athens, the famous old philosophers come back to life again in order to seek vengeance from an authorial figure called Mr. Frankness (П $\alpha \rho \eta \sigma i \alpha ́ \delta \eta \varsigma$ $<\pi \alpha \rho \rho \eta \sigma i ́ \alpha$, i.e. "outspokenness, frankness, freedom of speech"), a satirical voice or alias of Lucian's. ${ }^{4}$ This is configured as a reply to the humorous attack against philosophers which has been conducted in another Lucianic work, the

\footnotetext{
${ }^{2}$ I particularily acknowledge the other contributors of this volume who have offered me valuable comments on this text. Moreover, I owe many thanks to the participants of The Second Sophistic Workshop the University of North Carolina at Chapel Hill in 2019, especially to my co-organizers Janet Downie and David Stifler.

${ }^{3}$ Cf. the recent overview Baumbach, von Möllendorff 2017. A still masterly introduction is offered by Bracht Branham 1989.

${ }^{4}$ Cf. on Lucianic masks, Dubel 1994, Goldhill 2002: 63-67, Ní Mheallaig 2010, and Whitmarsh 2013: 243 .
} 
Philosophies for Sale (Vitarum Auctio), where ancient philosophers and their doctrines are ridiculed in a similar dialogical setting. In The Fisherman, the Cynic Diogenes of Sinope acts as the principal prosecutor against Parrhesiades, who thereby appears as the initial author of Philosophies for Sale. Although this is a statement uttered by a character within the imaginary world of satire, Diogenes' words appear to serve a programmatic, quasi-authorial commentary on - and a description of - Lucian's work as a whole. One of the most embittered charges of Diogenes' fierce attack reads as follows (Pisc. 25-27):

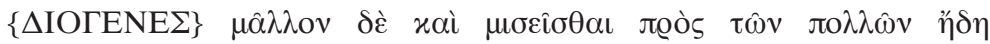

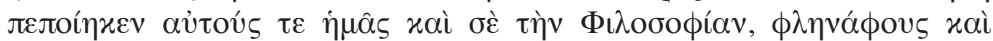

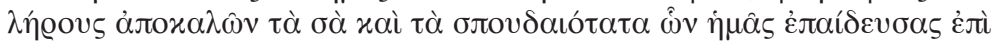

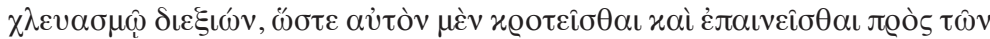

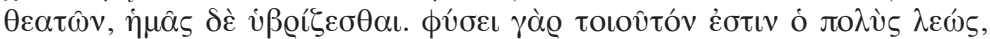

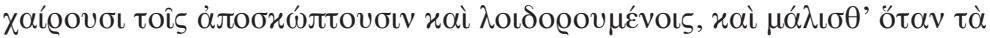

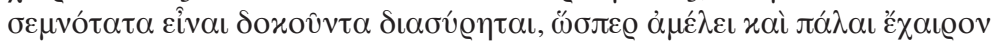

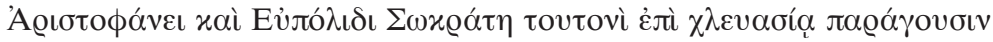

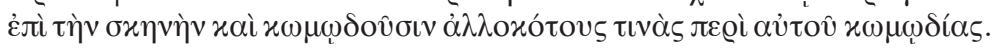

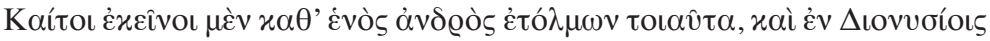

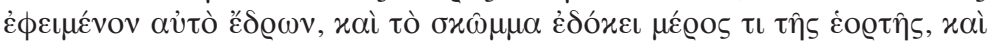

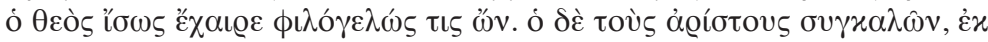

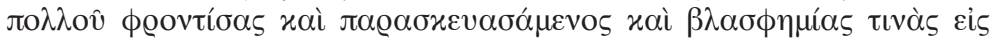

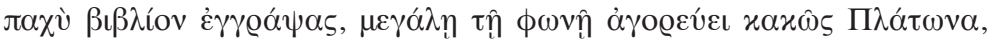

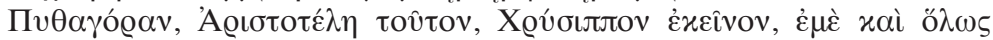

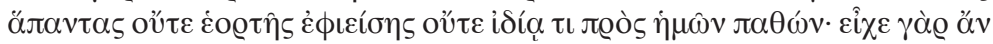

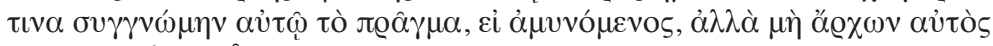

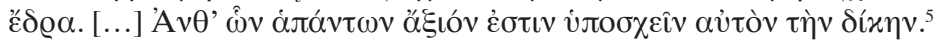

Diogenes: More than that, he has at last made people actually hate you, Philosophy, as well as us by dubbing your doctrines stuff and nonsense and rehearsing in mockery all that is most serious in what you taught us, so as to get applause and praise from his audience for himself and contumely for us. The common sort are that way by nature; they delight in jesters and buffoons, and most of all when they criticise what is held in high reverence. Just so in days gone by they took delight in Aristophanes [cf. the Clouds] and Eupolis [cf. fr. 395 PCG], who brought Socrates on the stage to make fun of him and got up monstrous farces about him. The playwrights, however, showed their boldness against only one man, and at the Dionysia, when it was permissible to do so, and the joking was considered part of the holiday, and the god, who loves his joke, no doubt was pleased. But this man brings the best people together, after a long period of thinking and preparing and writing down slanders in a thick roll, and then loudly abuses Plato, Pythagoras, Aristotle here, Chrysippus there, myself, and in a word, one and all, without the sanction of a holiday and without having had anything done to him personally by us. He would have some excuse

${ }^{5}$ Lucian's texts are quoted following the OCT editon of Macleod 1972-1987.

Araucaria. Revista Iberoamericana de Filosofia, Politica, Humanidades y Relaciones Internacionales, año $21, \mathrm{n}^{\circ} 41$. Primer semestre de 2019. Pp. 211-231. ISSN 1575-6823 e-ISSN 2340-2199 doi: 10.12795/araucaria.2019.i41.10 
for the thing, of course, if he had acted in self-defence instead of starting the quarrel. [...] For all this he ought to be punished... ${ }^{6}$

According to Diogenes in this Lucianic passage, the foremost playwrights of Old Comedy, among them Eupolis and Aristophanes, had the right to denigrate and poke fun only against a particular person, such as the philosopher Socrates, and only within the boundaries of the festive occasion of the Great Dionysia, the Athenian festival in honour of the god Dionysus. During the Dionysia, Athens - as far we can at least perceive from the comedies which survive-was bustling in an exceptional atmosphere. This atmosphere one might better understand with reference to Mikhail Bakhtin's four categories of the carnivalesque sense of the world, as they have been studied anthropologically ${ }^{7}$ as follows:

-free interaction between people of all backgrounds and the breaking-down of social barriers and boundaries to create a collective subjectivity ("free and familiar contact among people");

-a general acceptance of a behaviour free from social constraints and without the fear of consequences or sanctions by the dominant community ("eccentricity");

-a format that allows for particular spheres to be reunited, which are separated in daily life ("carnivalistic mésalliances");

-sacrilegious acts or events are allowed to occur without resulting punishment: otherwise strict rules of 'the sacred' can be profanated during carnival, giving way to mockery, blasphemy, obscenity (cf. the conception of $\alpha i \sigma \chi \varrho \circ \lambda \sigma \gamma i \alpha$ within the Greek iambic tradition), debasements, grotesque corporeality, etc. ("profanation").

To summarise the carnivalesque in Bakhtin's words: "Because carnivalistic life is life drawn out of its usual rut, it is to some extent "life turned inside out," "the reverse side of the world" ("monde à l'envers")." "The dramatic production of the comic poets, and on our evidence especially those by Aristophanes, bear an impressive testimony of such a topsy-turvy carnivalistic world within the Greek literary tradition. ${ }^{9}$

\footnotetext{
${ }^{6}$ This and all other translations of Lucian's texts are, unless otherwise specified, A. M. Harmon's, and are taken from Harmon, Kilburn, Macleod 1913-1967.

${ }^{7}$ As they have been developed by the Russian scholar in Bakhtin 1984: 122-123 (the quintessential ideas were already formulated in the 1929 original ed., whereas the $2^{\text {nd }}$ ed. in 1963 displayed a rather systematical account), taking as a starting point of analysis Menippean satire and its renewed formDostoevsky's work; cf. the chapter "Characteristics of Genre and Plot Composition in Dostoevsky's Works": pp. 101-180. On the aesthetics of carnivalization in Aristophanean Comedy, cf. the seminal study by von Möllendorff 1995 .

${ }^{8}$ Bakhtin 1984: 122.

9 On the carnivalization of and in literature, or, more concretely, in dramatic discourse, cf. in an
} 
In Lucian's dialogue The Fisherman the second ("eccentricity") and the fourth ("profanation") categories, the permission or authorization to perform sacrilegious acts, are subverted in particular. Here the newborn philosophers suggest various types of severe retaliation for all the injuries they have suffered in the course of Parrhesiades' satirical scolding of the philosophical life! According to them, 'the author' Parrhesiades has crossed a delicate line, and now they attribute to themselves the right to punish him for his 'sacrilegious behavior.' This is further illustrated by the philosophers' fierce attacks on Parrhesiades right at the beginning of the dialogue, which opens in the midst of action (Pisc. 1):

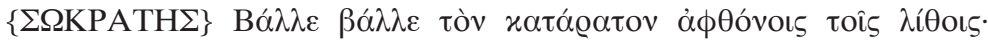

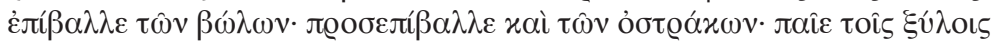

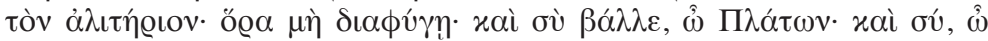

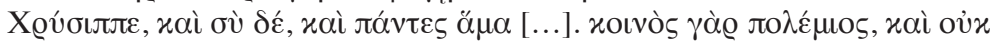

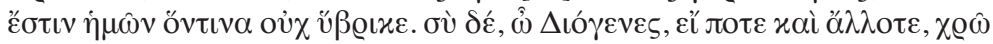

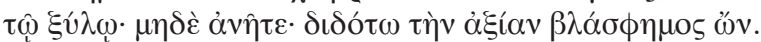

SOCRATES: Pelt, pelt the scoundrel with plenty of stones! Heap him with clods! Pile him up with broken dishes, too! Beat the blackguard with your sticks! Look out he doesn't get away! Throw, Plato; you too, Chrysippus; you too; everybody at once! [...] [F]or he is our joint enemy, and there is not a man of us whom he has not outraged. Diogenes, ply your stick, if ever you did before; let none of you weaken; let him pay the penalty for his ribaldry.

Socrates' last sentence is revealing here: Parrhesiades shall "pay

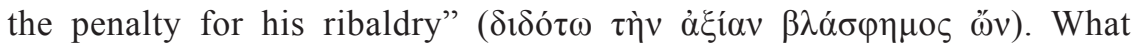
Diogenes finds primarily reproachable about Parrhesiades, this Lucian-like authorial figure, ${ }^{10}$ is that he mocks philosophers not within the confines of the carnivalesque festival, just as Old Comedy used to do, but rather in writings published throughout the entire year. ${ }^{11}$ Analogously to this, Lucian's satirical communication generally relies on an aesthetics of perpetual transgression: by detaching critique against moral misbehavior, double standards and vices from a singular occasion, and so depriving it of its former status of festive exceptionality, Lucian's character Diogenes paves the way to a new poetics of book satire. In turn, the innovative way

exemplary fashion von Möllendorff 1995: 73-109.

${ }^{10}$ On the comic models of Lucian's tendency to create a satirical alter-ego within his imaginative world, cf. Whitmarsh 2013: 243: "This technique, I think, owes more than has been recognized to the parabaseis of Aristophanes' comedies, which similarly slide between identification with and distantiation from the authorial voice".

11 One will not deny, however, that Lucian's resurrection of the dead philosophers itself clearly recalls carnival's juxtaposition of death and rebirth (the "joyful relativity of everything"), cf. Bakhtin 1984: 126. This is all the more so here, since The Fisherman displays several loans from Eupolis' Demes (fr. 99-146 PCG): Sidwell 2009. 
how Lucian constructs an authorial coherence becomes palpable throughout the corpus. As the resurrected philosopher Diogenes puts it in the passage quoted above (Pisc. 26), Parrhesiades, "after a long period of thinking and preparing and writing down slanders in a thick roll [...] then loudly abuses [...] one and all, without the sanction of a holiday and without having had anything done to him personally by us." The production of thick book-

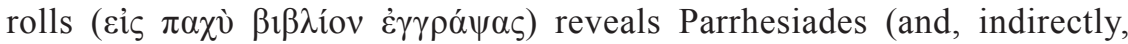
Lucian himself) as an assiduous publicist of satirical writings which are constantly handed over to a public readership. At the same time, which makes the statement still more relevant, the 'book' ( $\beta 1 \beta \lambda$ iov) is a reference to Lucian's Philosophies for Sale (Vitarum Auctio). Within the sequential order of Lucian's writing in the Medieval codex $\Gamma$ (the Vaticanus Graecus 90 , which contains 78 writings and dates from the $10^{\text {th }} \mathrm{c}$.), the eponymous manuscript for the text tradition $\gamma,{ }^{12}$ Vitarum auctor and Piscator are in fact set in juxtaposition and represented as libelli 27 and 28. Hence, the reference within the texts (Pisc. 25-27) correlates with the serial order of the texts in the manuscript tradition. This strongly suggests that they were set in concatenation by the author himself or by the editors of the corpus, which allowed for a sequential reading of the two writings coherently.

The Fisherman, as will soon become clear, belongs to a group of texts which also show clear cross-references to other writings within Lucian's corpus (such as Essays in Portraiture Defended, Apology, or The Runaways). By this sequential order of reading, it thereby offers an overall degree of authorial coherence, based on the satirical principle of ongoing (and thereby unexceptional) transgression. I shall discuss these references which crisscross Lucian's texts in the following section.

\section{Hidden biobibliography, or The making of the Corpus Lucianeum}

Apart from the reference in The Fisherman (lib. 28), which can be read as a sequel of the earlier Philosophies for Sale (lib. 27), we come across three other passages in Lucian's work in which apparently quite different writings are yoked together through explicit references. I shall briefly mention and discuss each of them, before going on to generally refer my observations to an important writerly principle of the Corpus Lucianeum as a whole.

12 On the Schriften-Akoluthien in Lucian's manuscript tradition, cf. Mras 1911. 


\section{Apology for "Salaried Posts in Great Houses" (Apologia pro Mercede Conductis)}

In this short speech, ${ }^{13}$ the narrating first-person voice, who is a sophisticated writer, defends himself against a critical reader named Sabinus who has read Lucian's On Salaried Posts (De Mercede Conductis). ${ }^{14}$ The critic now accuses the author for not living up to the expectations he has created in his own texts. For whereas he scolded the materialistic interests of pseudo-intellectuals and false philosophers seeking employment in rich Roman houses in the earlier work, Sabinus now objects to his lucrative rhetorical activity within the Roman administration. The Apology starts as follows (Apol. 1):

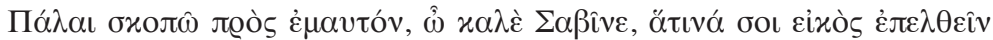

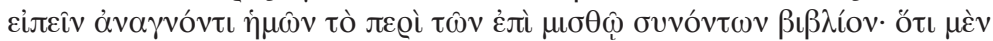

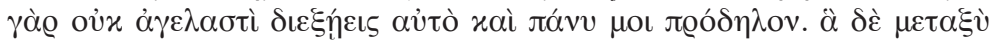

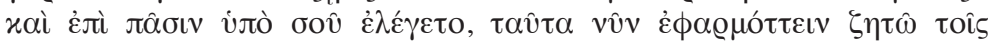

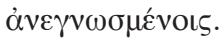

I have long been wondering, my dear Sabinus, what it probably occurred to you to say now that you have read my essay on "Salaried Posts in Great Houses." It is quite certain that you had a good laugh when you read it; but I am trying now to fit the detailed and general comments you made to the text. (transl. K. Kilburn)

Lucian's Apology thus appears as a continuation, as it were, of the $O n$ Salaried Posts whose title is referred to in the opening passage. We, the readers, are invited to follow the steps of the model reader Sabinus and read that text before advancing with the Apology, which takes the former work as a starting point for the satirical defence of its own author-figure, the first-person voice of the text.

The manuscript tradition, however, has not combined this pair of writings, since On Salaried Posts occupies position 36 within $\Gamma$, and the Apology appears as number 65 . There might have been two main reasons for this clear separation between the two texts. First, it could be argued that the reference to Merc.

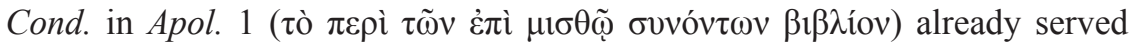

${ }^{13}$ On Lucian's Apology, as well as the Lucianic technique to create an author-figure defending himself for his literary production, cf. Hafner 2017. By the title Apology, Lucian wittily alludes to Socrates' defence speech which had become significant-apart from its Xenophontian versionthrough Plato's literary legacy. On the other hand, by adopting the poetical licence of Old Comedy, in which poets defended themselves against accusations of their dramatic production (e.g. as in Aristophanes' Clouds), Lucian in the Apology constructs a poetics which is recurrent all along his work: the project of a conjunction between Platonic (or Socratic) literature and Old Comedy.

${ }^{14}$ On this text, which depicts in several phases the journey of a Greek $\pi \varepsilon \pi \alpha 1 \delta \varepsilon v \mu \varepsilon$ vo Roman patron's house and the humiliating social rituals he performs in order to become a client of the wealthy patron, cf. Hafner $2017 \mathrm{a}$.

Araucaria. Revista Iberoamericana de Filosofia, Politica, Humanidades y Relaciones Internacionales, año $21, \mathrm{n}^{\circ} 41$. Primer semestre de 2019. Pp. 211-231. ISSN 1575-6823 e-ISSN 2340-2199 doi: 10.12795/araucaria.2019.i41.10 
as a crystal clear mnemonic reminder of the former libellus to the reader. Secondly, the Apology itself is again situated within a group of formally and/or thematically related texts: ${ }^{15}$ within this group of writings, we come across the Apology's remarkable similarities to other rhetorical set-pieces (cf. lib. 53 and 54 ) and texts in which the speakers choose as a theme the relationship between themselves and their audience/readership (cf. lib. 60, 62, 63, 66, 67, 68, the so-called $\pi \rho \circ \lambda \alpha \lambda 1 \alpha$ í, i.e. "rhetorical prefaces," "introductory remarks"). On the other hand, lib. 64 and 66, the texts which are placed either side of the Apology, thematically treat the efforts made to gain sufficient support by a patron. Lib. 64 and 67 also display an apologetic attitude, which is to say: the author(s) or editor(s) of codex $\Gamma$, following structural and thematical aspects, grouped their texts in this order in such a way as that they would be read as a linear, coherent cycle. Evidently, the author or his later revisers considered particular structural elements and motifs as a signature of this part of the œuvre.

\section{Essays on Portraiture Defended (Pro Imaginibus)}

In accordance with the self-reference to Merc.Cond. at the start of Apol., another combination of two texts displays a remarkable sequentiality and linearity, even though they are divided from each other and placed at different positions in Lucian's work. This is the case of the diptych between the dialogues Essays of Portraiture (Imagines, lib. 43) and Essays on Portraiture Defended (Pro Imaginibus, lib. 50), in which the latter, comparably to the Apology, at first glance appears to be a palinode of a preceding text. ${ }^{16}$ In the Imagines, the character Lycinus is found ecstatically describing a beautiful woman to his dialogue partner Polystratus, of whom he had caught sight while she passed by him with her royal entourage. Lycinus makes use of reference to various great masterpieces of art in order to describe the woman's portrait and to vividly bring it to 'life' again. Polystratus, for his part, completes the - in his view - incomplete portrait with positive ethical traits. Then he utters towards the end of the dialogue (Im. 23):

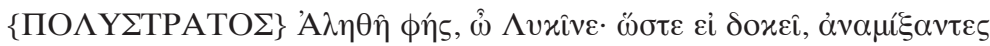

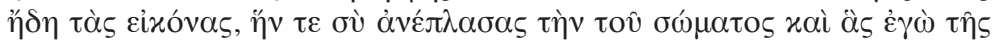

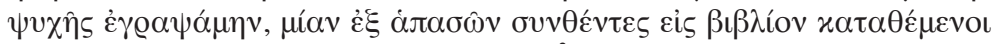

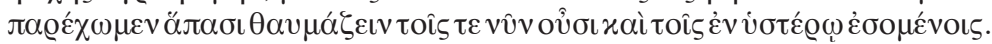

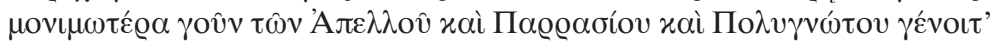

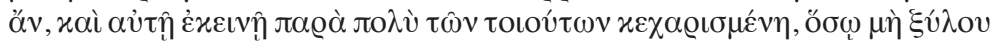

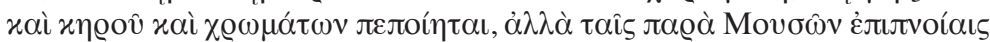

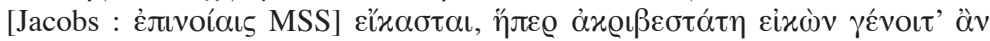

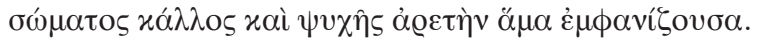

15 On this phenomenon, cf. Hafner 2017: 50.

${ }^{16}$ Cf. on the junction of Im. and Pr.Im., Bretzigheimer 1992 and von Möllendorff 2004. Cf. also Sidwell 2002. 
Polystratus: You are right, Lycinus. So, if you are willing, let us put our portraits together, the statue that you modelled of her body and the pictures that I painted of her soul; let us blend them all into one, put it down in a book, and give it to all mankind to admire, not only to those now alive, but to those that shall live hereafter. It would at least prove more enduring than the works of Apelles and Parrhasius and Polygnotus, and far more pleasing to the lady herself than anything of that kind, inasmuch as it is not made of wood and wax and colours but portrayed with inspirations from the Muses; and this will be found the most accurate kind of portrait, since it simultaneously discloses beauty and nobility of soul.

The book ( $\beta$ i $\beta \lambda$ iov) mentioned here by Polystratus is, of course, the libellus Lucianeus itself, the Essays on Portraiture, whose future (at least from the dialogue partners' perspective) metamorphosis into a material book and subsequent circulation among an audience is anticipated in the text by the same

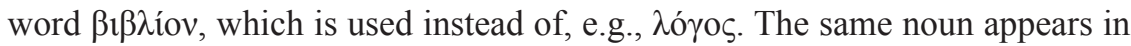
Apology 1 and The Fisherman 26 to designate the previous texts On Salaried Posts and Philosophies for Sale respectively. ${ }^{17}$ Compared to the statues of Apelles and other famous painters and thanks to the Muses, the material book according to Polystratus will — to elaborate the Thucydidean pledge of $\kappa \tau \tilde{\eta} \mu \alpha$ $\dot{\varepsilon} \varsigma \alpha i \varepsilon i-{ }^{18}$ be able to freely circulate and reach many more admirers than the immobile (and immovable) works of art. The temporal extension of Lucianic literature, which is underscored by Diogenes in The Fisherman, corresponds in the Imagines with the local or geographical extension of Lucian's popularity among his readers.

In the corresponding text, Pro Imaginibus, however, Polystratus acts as a messenger of the beautiful woman, conveying her reply to his friend Lycinus (which constitutes, as in the Apology, another internal response by a critical reader), ${ }^{19}$ in which she criticizes Lycinus and accuses him of open and

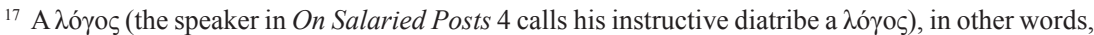

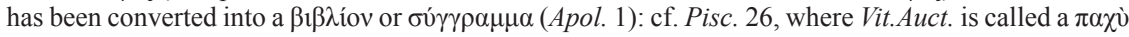
$\beta 1 \beta \lambda$ íov. In Essays on Portraiture 23, in turn, the actual dialogue is anticipated as $\beta 1 \beta \lambda$ íov which will be available to future readers. In the readers' minds, all these $\beta \imath \beta \lambda$ í $\alpha$ form part of a œuvre as a sort of mental superstructure, which is Lucian's imaginative biobibliography.

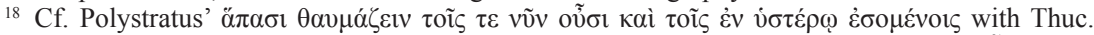

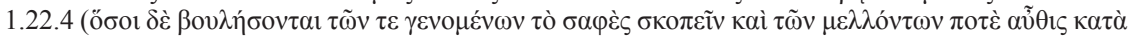

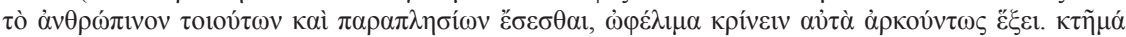

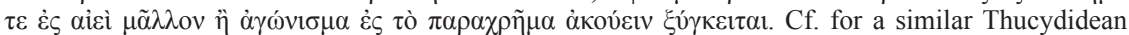

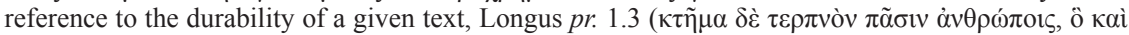

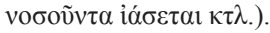

19 The discussions between an authorial figure and a critical reader in Lucian's Apology, Essays on Portraiture Defended, and Fisherman shed some light onto a vivid discourse about the reception of literary works and represent an expression of contemporary $\pi \alpha 1 \delta \varepsilon i ́ \alpha$. Evidently, the audience of Lucian's writings could recognize themselves in the internal figure of the critical reader, who serves as a mediating example for the real and non-controllable audience. By the mediation of such internal figures, readers could take part in debates of various topics such as questions concerning valid and 
excessive flattery. Through her spokesman Polystratus, she gives Lycinusagain the fictitious representative of the satirical author - the following advice (Pr.Im. 14):

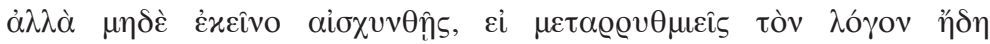

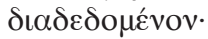

Do not be ashamed, either, to reshape the essay after it has been put into circulation.

The woman, whose beauty was discussed in the earlier Imagines, thus recommends a new edition or revision (cf. $\mu \varepsilon \tau \alpha \rho \rho v \theta \mu 1 \varepsilon i \varsigma)$ of a text that is

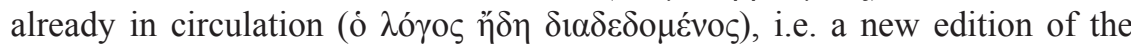
Imagines. ${ }^{20}$ In accordance with the passages quoted above, the more ore less explicit intratextual references again invite the readers to connect a Lucianic writing to a subsequent text. On the other hand, the $\mu \varepsilon \tau \alpha \rho \rho v \dot{\theta} \theta \mu \mathrm{\sigma} \varsigma$ of this already

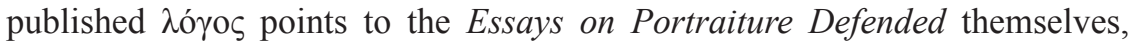
which thus appears to be an altered or revised version of its precursor text. Here it is again a fictitious character within Lucian's satirical world, the highly praised woman, who through her mouthpiece Polystratus makes comments on the work itself.

Finally, and to speak more generally, we have in all three cases observed that fictitious trial scenarios, comprising both the prosecuting and the defence speeches are typical markers of intratextual (and to this extent authorial) coherence in Lucian's corpus. Of these, the latter group (of defence speeches) include an apology delivered by an author-like satirical figure, such as in Pisc., Apol., and Pr.Im.

\section{A short excursus on the art of Lucian's apologetics}

Lucian's apologetics bears witness to the innovative character of his new form of satirical writing, which has developed out of diverse literary traditions. He introduces author-like figures who are willing to defend themselfes in fictitious trials against critics of their literary productions. In each apologetic, however, the satirical voice refutes the opponents' allegations in an eloquent way, and each time the reproaches raised against this fictitious author-protagonist enable the latter to elaborate his own viewpoint in a virtuoso manner, ${ }^{21}$ for instance, the speaker in the Apology, just as in The Fisherman and the Essays

invalid arguments in rhetoric. On such participatory and dialogical forms of deep, performative learning in contemporary $\pi \alpha 1 \delta \varepsilon i ́ \alpha$, cf. von Möllendorff 2004 and Johnson 2010: 168.

${ }^{20}$ Cf. Bompaire 1993: LII.

${ }^{21}$ On satirical self-dramatizations in the context of courtroom scenes, cf. Branham 1989: 31-37 and Goldhill 2002: 71. 
in Portraiture Defended, does not feel obliged to defend his moral integrity. Contrary to the plausible expectation that the speaker will request a pardon in the form of a remorseful palinode, ${ }^{22}$ the viewpoint under attack is in each case underpinned and further highlighted. Particularly in the Apology, the speaker not only mocks serious and repentant apologies, but also points out their rhetorical lack of originality (Apol. 8-10). ${ }^{23}$ Hence, the apologetic speeches rather serve to expand the satirical potential of their previous texts ${ }^{24}$ and to ascribe further prestige to the authorial persona, who takes full advantage of the accusations, and thereby converts the alleged scandal into a manifestation of his own literaryrhetorical expertise. ${ }^{25}$ At the same time, the impression becomes inavoidable that the speeches in defence ( $\dot{\alpha} \pi \mathrm{o} \lambda \mathrm{o} \gamma \dot{\alpha} \alpha)$ turn out to be basically exercises in epideixis (display-speeches). ${ }^{26}$ The controversies between prosecution and defence, a recurring structural setting in Lucian's texts, demonstrate that our writer applied a refined rhetorical machinery to his texts: namely, antilogy, one of the finest instruments in the sophists' toolbox. By speaking in utramque partem (pro and contra), authors such as Lucian throughout antiquity displayed their rhetorical abilities. ${ }^{27}$

\section{Zeus takes mercy on Lucian's readers: the opening of the Runaways (Fugiviti)}

Yet there is another work in the Lucianic corpus which bears clear references to a precursory text. Lucian's Runaways (Fugitivi, lib. 56), in which impostor philosophers - the central figures of the dialogue-are accused of seeking to seem rather than to be wise, begins straightaway with a reference to the death of the charlatan and "wonderworker" ( $\theta \alpha v \mu \alpha \tau o \pi$ oiós, as Apollo calls him ironically) Peregrinus, who has thrown himself into a burning rogue and thus has come to a wretched end at the Olympic Games (Fug. 1):

${ }^{22}$ The word $\pi \alpha \lambda \iota \omega \delta$ í $\alpha$ appears both in Apol. 1 and Pr.Im. 15.

${ }^{23}$ Cf. Obermeier 1999: 42.

${ }^{24}$ Cf. Saïd 1993: 265: „enfin Lucien tente de se disculper en satiriste. [...] [I]1 établit la cohérence de sa conduite de manière paradoxale, en montrant qu'en fait il a toujours été payé ou, si l'on veut, vendu".

${ }^{25}$ Cf. Branham 1989: 28-37, esp. 31-32 ("self-advertisement posing as self-defense"), Hafner 2017: $36-43$.

${ }^{26}$ Cf. Branham 1989: 30-31, Obermeier 1999: 42: "Lucian emerges from the comedy vindicated, in an intertextual way re-affirming the initial premise in [Vit.Auct.], but having turned seeming selfcriticism and retribution into another triumph of his verbal craft."

${ }^{27}$ Bruns 1888: 99. The readers of these texts are made listeners or even judges of a court case: as the audience addressed in a performance, they are offered to decide about the validity of a given argument or about the outcome of a trial: cf. Bruns 1888: 101: „Die Vortheile des apologetischen Vorgehens liegen ja auf der Hand. Die Theilnahme des Hörers ist von vornherein stärker in Anspruch genommen..."

Araucaria. Revista Iberoamericana de Filosofia, Política, Humanidades y Relaciones Internacionales, año $21, \mathrm{n}^{\mathrm{o}} 41$. Primer semestre de 2019. Pp. 211-231. ISSN 1575-6823 e-ISSN 2340-2199 doi: 10.12795/araucaria.2019.i41.10 


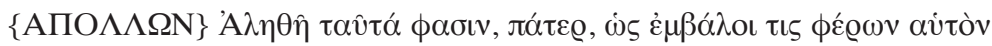

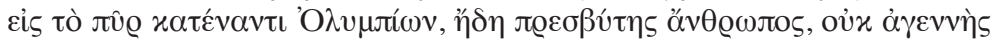

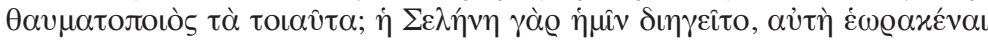

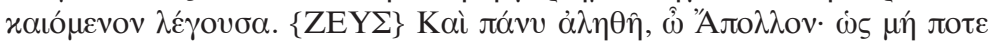

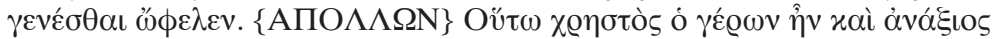

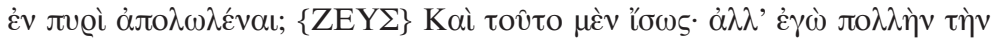

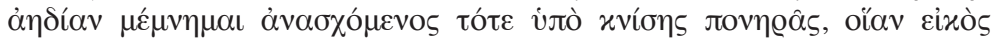

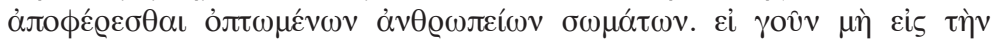

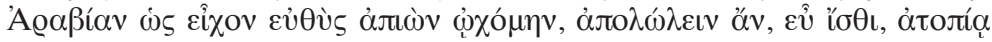

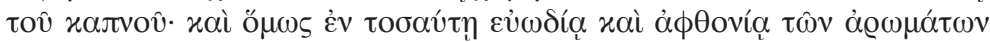

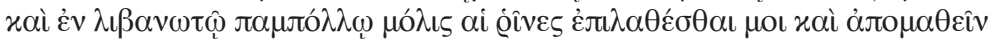

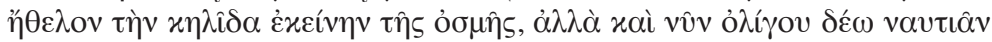

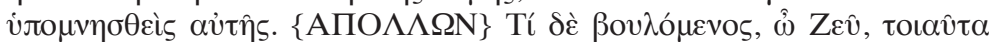

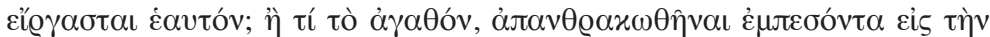

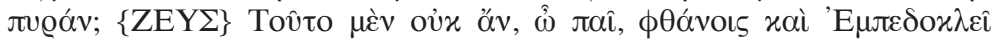

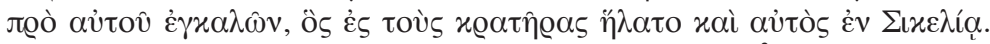

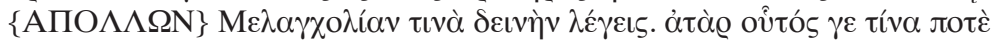

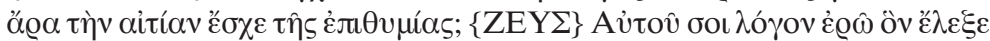

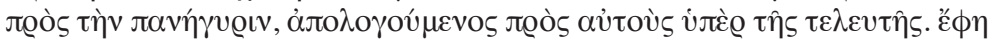

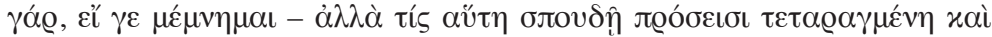

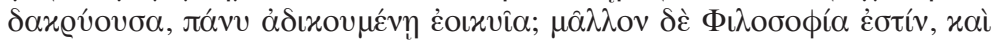

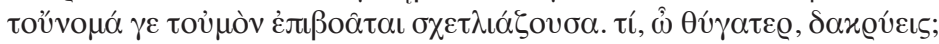

ApolLo: Is the report true, father, that someone threw himself bodily into the fire, in the very face of the Olympic festivities, quite an elderly man, not a bad hand at such hocus-pocus? Selene told me, saying that she herself had seen him burning._Zeus: Yes, quite true, Apollo. If only it had never happened!-ApolLo: Was the old man so good? Was he not worthy of a death by fire? -Zeus: Yes, that he was, very likely. But my point is that I remember having had to put up with a great deal of annoyance at the time on account of a horrid stench such as you might expect to arise from roasting human bodies. In fact, if I had not at once gone straight to Araby, I should have come to a sad end, you may depend on it, from the awfulness of the reek. Even as it was, amid all that fragrance and abundance of sweet scents, with frankincense in a profusion, my nostrils consented to forget and unlearn the taint of that odour; why, even now I almost retch at the memory of it!-Apollo: What was his idea, Zeus, in doing that to himself, or what was the good of his getting incinerated by jumping into the blazing fire?-Zeus: Well, that criticism, my boy, you had better address first to Empedocles, who himself sprung into that crater in Sicily.-APOLLo: A terrible case of melancholia, that! ${ }^{28}$ But this man-what reason in the world did he have for wanting to do it?-Zeus: I will repeat for you a speech of his own, which he delivered to the assembled pilgrims, defending himself before them for putting an end to himself. He said, if my memory serves me-But who is this woman coming up in haste, excited and tearful, like someone suffering great wrongs? Stay, it is Philosophy, and she is calling upon me by name, in bitterness of spirit. Why the tears, my daughter?

${ }^{28}$ On the alleged melancholia of Empedocles which eventually prompted his suicide, cf. Lucian's Dialogue of the Dead 6.4 .

Araucaria. Revista Iberoamericana de Filosofía, Politica, Humanidades y Relaciones Internacionales, año $21, \mathrm{n}^{\circ} 41$. Primer semestre de 2019. Pp. 211-231. ISSN 1575-6823 e-ISSN 2340-2199 doi: 10.12795/araucaria.2019.i41.10 
As is made clear in this frame dialogue between Apollo and Zeus, the two extremely different personalities, the arch-villain Peregrinus and the famous Presocratic philosopher Empedocles of Acragas are said to have shared at least the same manner of dying by throwing themselves into fire and having been burned alive. ${ }^{29}$ The whole episode surrounding Peregrinus is, of course, a reference to Lucian's Death of Peregrinus (lib. 55), to which the beginning of

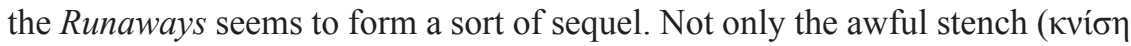
$\pi$ ovepá) rising from the rogue or the contrast to Empedocles' noble end, but also the Selene episode is a reminder of Peregrinus (Peregr. 36), where the goddess of the moon is forced to watch the miserably engineered torchlight procession of Peregrinus and his followers. ${ }^{30}$ It is amusing, however, that Zeus, who is about to repeat for Apollo the final speech for defence which Peregrinus

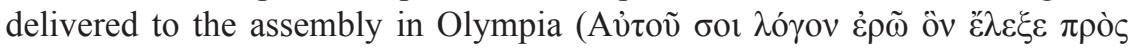

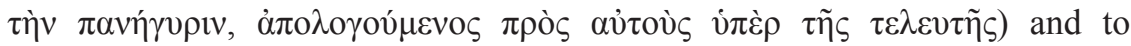

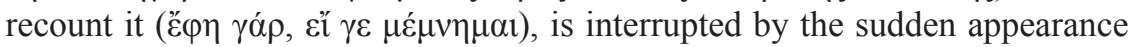

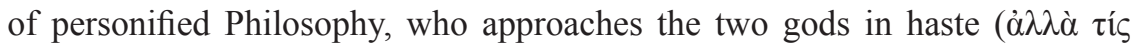
$\alpha$ $\tau \tau \eta \sigma \pi 0 v \delta \tilde{\eta} \pi \rho \sigma^{\circ} \sigma \varepsilon 1 \sigma 1 \kappa \tau \lambda$.). At this point, we gain the impression that Zeus (or the author Lucian) wanted to spare us, the readers, namely a wearisome and disgusting second reading of the death of Peregrinus, which has already been exuberantly narrated in the previous Peregrinus!

Given the close connection with the other explicit coupling of lib. 27 and 28, The Sales of Philosophies and The Fisherman (see above), the Peregrinus and the Runaways are - not surprisingly_-presented as concatenated writings as well. They serve as two sequential texts within the manuscript tradition of $\gamma$ (the libelli 55 and 56).

\section{Dead-end intratextuality: the closure of the True Stories (Verae Historiae 2.47)}

In contrast to the above mentioned couplings, in Lucian's famous True Stories we are left with the mere announcement of a future sequel. The end of this novel-like tale about fantastic wanderings into a whale, into outer space and back to earth again, reads as follows (Ver. Hist. 2.47):

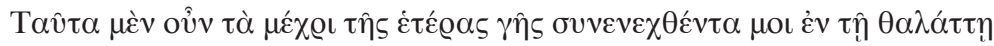

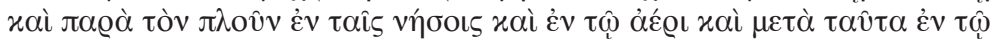

\footnotetext{
29 The anecdote of Empedocles' death by jumping into the crater of Mount Etna could have been inspired by the assonance (paronomasy) of his name 'E $\mu \pi \varepsilon \delta \circ \kappa \lambda \tilde{\eta} \varsigma$ and the verb $\dot{\varepsilon} \mu \pi \eta \delta \tilde{\alpha} \nu$ ("to leap,

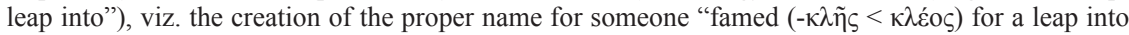
something," a pun which may date back up to pre-Hellenistic times, when itacism had not yet become established.

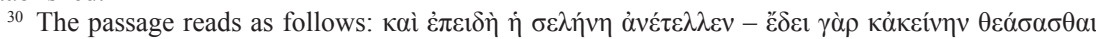

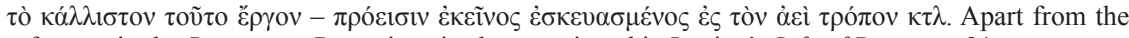
reference in the Runaways, Peregrinus is also mentioned in Lucian's Life of Demonax 21.
} 


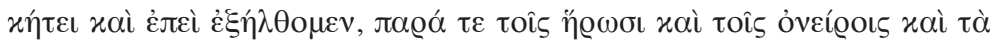

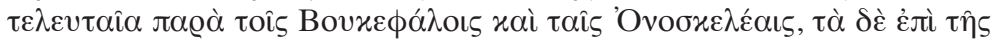

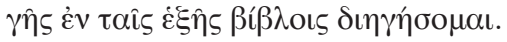

Thus far I have told you what happened to me until I reached the other world, first at sea, then during my voyage among the islands and in the air, then in the whale, and after we left it, among the heroes and the dreams, and finally among the Bullheads and the Asslegs. What happened in the other world I shall tell you in the succeeding books.

In the last lines of the True Stories, the primary narrator inserts a proleptic reference to a tale which he will narrate in "subsequent books" ( $\dot{\varepsilon} v \tau \alpha \tilde{c} \zeta \dot{\varepsilon} \xi \tilde{\eta} \varsigma$

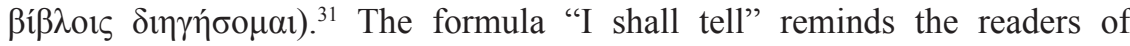
countless announcements made in the previous two books of the True Stories, by which the storyteller promises to move from one topic to the next, such as

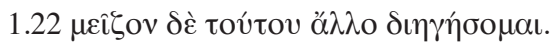

But I will tell you something else, still more wonderful.

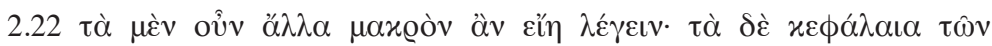

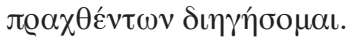

The full details would make a long story, but I shall tell the principal things that they did.

At the end of the True Stories, however, no other books are going to redeem the deceptive narrator's pledge about his future tales. This (intentionally) open and fragmentary end ${ }^{32}$ or, in other words, this "dead-end" intratextuality is best explained as a playful game with the experienced reader, who is already acquainted with the announcements by Lucianic characters that a given text could be read as a prequel or sequel, as we have observed in the examples discussed above. ${ }^{33}$

\footnotetext{
31 The allegation that the first-person narrator will remain consistent in other writings is another wrong track.

32 On this intratextual closure, cf. Whitmarsh 2011: 185-186, Ní Mheallaig 2014: 182: "Lucian's explicit is explicitly anti-closural, as it leaves the reader with the expectation that Books 1 and 2 constitute merely one section of a larger work whose remains are lost; in this way, Lucian creates the illusion that True stories itself is an incomplete, fragmentary text, and invites the reader to speculate what those 'lost books' might have said."

33 Announcements concerning fictitious continuations also occur at the final sentences of Lucianic dialogues, such as Philosophies for Sale (\$27), Anacharsis ( 40 vं $\pi \varepsilon \rho \beta \alpha \lambda \omega \mu \varepsilon \theta \alpha)$, or (Ps.?) Solecist $(\S 12 \dot{\alpha} v \alpha \beta \alpha \lambda \omega \dot{\omega} \varepsilon \theta \alpha)$.
} 


\section{Lucian's hidden biobibliography - conclusions and further considerations}

Lucian's serial continuations and his yoking together of apparently quite disparate texts across the corpus might seem a characteristic of the author's writing itself. At the same time, the couplings transcend the single texts individually: rather, the technique enables Lucian - through his fictitious characters - to comment on his diverse writings and to ensure their readability within a corpus marked by coherence and unity. By interlinking, or better intralinking what are otherwise more or less scattered texts together in order to form linear sequences, the Corpus Lucianeum - in the virtual absence of a consistent authorial figure - becomes the only relevant authoritative frame that we have.

By establishing his own distinctive modes of intratextuality, Lucian thus historicizes - and canonizes - his œuvre. The cross-references which we have analyzed may best be considered to function as markers of integration within the confines of the same œuvre. Francesca Martelli's observations concerning the processes of revision, to which the Roman poet Ovid subjects many of his writings, in my view carries weight for Lucian's writings as well:

In forging connections between the disparate texts that constitute his œuvre, revision makes them point collectively to a single author and thereby produce an authorial referent that transcends the individual works that bear his name. Revision thus reinforces the identity of the author 'Ovid' [we may put 'Lucian' here] by integrating the various works transmitted in this name. And yet, paradoxically, the revisions that characterise these texts function just as importantly as a mark of their author's disappearance. ${ }^{34}$

The various self-references found in the Corpus Lucianeum, ${ }^{35}$ whilst pointing ultimately to its unity, also offer the readers a glimpse of the dynamic genesis and the authorial making of the ouvre itself. By interlinking the Philosophies for Sale (lib. 27) with The Fisherman (lib. 28), On Salaried Posts (lib. 36) with Apology for Salaried Posts (lib. 65), Essays on Portraiture (lib. 43) with Essays on Portraiture Defended (lib. 50), ${ }^{36}$ and the Death of Peregrinus (lib. 55) with Runaways (lib. 56), Lucian has his characters comment on those concatenations and adumbrate his own (auto)biobibliography, as it were, in statu nascendi, by which one should include the biography of all writings from

${ }^{34}$ Martelli 2013: 230.

35 On the conception of Werkpolitik, i.e. the politics, or poetics, of a literary legacy, a system of self-canonizing references established by authors mostly in their late works or retractationes, cf. Scheidegger-Lämmle 2017.

${ }^{36}$ Bretzigheimer 1992: 162-166 and von Möllendorff 2004: 15, n. 37 favour a sequential reading of Im. and Pr.Im. On Vit.Auct. and its sequel Pisc., see Bruns 1888: 97, according to whom the riddles of Philosophies for Sale are finally solved for the readers in the Fisherman. Anderson 1976: 166, n. 46 speculatively assumes the loss of further sequels in the course of the manuscript tradition.

Araucaria. Revista Iberoamericana de Filosofia, Politica, Humanidades y Relaciones Internacionales, año $21, \mathrm{n}^{\circ} 41$. Primer semestre de 2019. Pp. 211-231. ISSN 1575-6823 e-ISSN 2340-2199 doi: 10.12795/araucaria.2019.i41.10 
the corpus which were attributed to and transmitted under the name of the author Lucian. Whereas, in other words, the identity of the satirical voice in the text constantly changes, the œuvre itself, which we perceive mainly in the course of a dynamic reading process, resists any form of transformation. Lucian's texts are set within a sequential — not static, yet stable — narrative, thus rendering the portrait of a literary trajectory which diachronically crystallizes out of its diverse writings. ${ }^{37}$

At the end of the True Stories (2.47), as we have observed, such intratextuality leads to a referential dead-end, although even this constitutes a playful ironization of Lucian's textual continuations and a literary game for his experienced reader, who is already used to follow the links which criss-cross the œuvre. Once more we could refer to Zeus in The Runaways 1 (lib. 56), who breaks off to retell the events which were already narrated in the Death of Peregrinus (lib. 55).

Lucian's own self-conscious engagement with his literary achievement is an integral aspect of his corpus as a whole. The endeavour to protect and to sign, as it were, his authorship resulted in a manifold system of intratextuality. On the other hand, the coherence of the œuvre and the ever-recurring elements of his satirical voice - both formal, such as dialogicity and colloquialism, or thematic, such as the mocking of pseudo-intellectuals - proved a decisive factor in influencing the perception of Lucian's style in later times. Indeed it was strongly due to recurrent formal and thematical elements that the texts could be judged as Lucianic by contemporary and later audiences. On the other hand, this satirical voice could have compelled later authors to look to adapt this style themselves and, though highly unlikely, to enter the corpus. Although in Imperial Times the processes of text production, distribution, circulation, and transmission changed from the rising book trade and may have become much more common and widespread than in earlier times, there never existed any solid institutions to ultimately protect literary authorship as a kind of "intellectual property". Furthermore, readers used to identify texts by and with particular authors whom they revered and canonized, and later writers sought to emulate their style and even hoped to join their work. ${ }^{38}$ Through work-related

${ }^{37}$ Lucian establishes such a sequential micro-narrative, e.g., in the three Scythian dialogues: Hafner 2015.

${ }^{38}$ Accordingly, several pseudepigraphical writings have been identified in the manuscript tradition of Lucian's œuvre, which as the creative fruits of collaborative authorship still wait to be treated comprehensively in future scholarship. Whereas the genuineness of Octogenerians (Macrobioi or Longlivers), Soloecista, Lucius or The Ass, Amores, Praise of Demosthenes, Halcyon, Podagra, Ocypus and Cynicus is doubted, even though they appear in $\Gamma$ (Vaticanus Graecus 87 ) and other reliable manuscripts, the Letters, the mimetic-dramatic dialogues Philopatris (The Patriot), Charidemus, Nero, the Epigrams, and the byzantine Timarion $\left(12^{\text {th }} \mathrm{c}\right.$.), the latter being a Menippeanlike journey to the underworld, are considered pseudepigraphical. The best discussion of the byzantine pseudepigrapha is still offered by Hunger 1978: 149seqq. On the epigrams, cf. Baldwin 1975 and Fernandez Robbio, this volume. The doubted and spurious works, apart from the Scythian Letters and 
intratextuality and the establishment of a system of cross-references, Lucian might have aimed at securing authority and authorship by attempting to protect his work against the addition of such pseudepigraphical fan fiction.

That is to say that, a long time before the introduction of the first copyright legislation, controversies about the author of a literary text seemed to be an everyday occurrence. Lucian's contemporary Galen, for example, laments that literary fakes circulated under his own name. ${ }^{39}$ Galen repeatedly mentions the danger of uncontrolled circulation of writings, since in this process the authorship of a text could easily be doubted..$^{40}$ Therefore, Lucian's intratextual references could serve to reinforce the author's identity by preventing others from writing in his name and forestalling questions of authenticity or spuriousness. The coupling of several writings could thus aim at securing authorship (and ownership) against uncontrolled circulation. From this perspective, the construction of single authorship can be considered as anultimately futile - attempt to resist the widespread practices of collaborative authorship and fan fiction: by supplementing his own writings with other texts, Lucian himself acted as his first subsequent revisor and thus anticipated a role which later authors were willing to play. The pseudepigraphical writers, far from being plagiarists or thieves of Lucian's intellectual creation (which was at least the ancient perception concerning imitation and emulation), ${ }^{41}$ rather created an authorial fiction of becoming Lucian themselves and of producing inspiring aesthetic experiments under their revered master-author's name (primary pseudepigraphy). Other works were in due course considered as Lucianic or at least worth of Lucian (secondary pseudepigraphy), being exquisite products of literary emulation. ${ }^{42}$

From a later perspective on Lucian's work, one cannot, however, doubt the fact that the addition of the pseudepigraphic texts itself was - paradoxically — a reliable guarantee that there indeed was a perception of an existing, somewhat coherent Corpus Lucianeum, to which later authors sought their texts to be attributed. The mere employment of a satirical voice, or the recurrent use of

other epistles, are provided with translation in vol. 8 of Harmon, Kilburn, Macleod 1913-1967, cf. Macleod's introduction ix- $\mathrm{x}$.

39 Cf. Gal. HNH I Kühn vol. 15 24, 104-105 = CMG V 9.1 p. 14-15, 54-55, HNH II Kühn vol. 15 praef. $109=$ CMG V 9.1 p. 57, Lib.Prop. Kühn vol. $198=$ SM 2 p. 91 = Boudon-Millot Prol .

${ }^{40}$ Hanson 1998: 30 identifies one particular reason of this problematic confusion: "publication of one's writing throughout antiquity consisted of giving out copies to one's friend with the expectation that they would share the work with others and arrange for additional copies to be made". Ní Mheallaigh 2014: 20-22 analyses Lucian's comparisons of the irreversible distribution of texts with fragile objects in Lucian.

${ }^{41}$ There existed, of course, complaints about plagiarism in antiquity, e.g. by Martial. On this problem, see generally Stemplinger 1912, Ziegler 1950, Speyer 1971, Syme 1972, Mülke 2008, Martínez 2011, Peirano 2012: 1-35, McGill 2012: 10-12. On plagiarism in Lucian, cf. Hafner 2017b: $256-258$.

${ }^{42}$ On pseudepigraphy as biofictional commentary or supplement of a master-author, cf. Peirano 2012 and 2012a. 
typical and recurrent patterns within the genuine texts, by contrast, did not sufficiently ensure Lucian's authorship, since it obviously prompted other writers to try their luck at the same collaborative experiment of literary emulation.

\section{Epilogue}

In recent studies, Lucian has been dubbed a metaleptic author, who manifests himself within the fictional texture of his own works, disguised only by pseudonyms which, at the same time, mark non-identity (such as 'Parrhesiades', 'Tychiades', 'Lycinus', the anonymous Syrian, etc. . ${ }^{43}$ Contrary to the many masks which the author Lucian adopts, in order thereby to become himself a part of the fictional textual universe, the pervasively self-referential intratextuality that we have examined serves, I have argued, a more practical purpose: to secure Lucian's authorship over the œuvre and to anticipate the latter's distribution and reception among a wider audience. This applies even though it is constructed by Lucianic characters from the inside of the textual universe. A much stronger claim of authorship might have been the author's name itself, ${ }^{44}$ which only rarely appears within and more often outside of the texts themselves, and yet which functions as a connecting principle throughout the author's œuvre. ${ }^{45}$ His intratextual (auto)biobibliography, however, became an important metapoetic frame of reference which ensured the works' readability as an organic and coherent literary corpus: well-publicized, not bound to single occasions, and thereby far away from carnivalesque exceptionality.

43 Cf. on this Whitmarsh 2001: 248-253 and Whitmarsh 2009. On the spectrum of Lucianic personae, cf. Dubel 1994, Goldhill 2002: 63-67, and Ní Mheallaig 2010. Moreover, recurrent patterns or personnel in Lucian's texts (as, e.g., the appearance of the figure 'Momus' shows: cf. Flores Militello in this volume) function as strong markers of coherence between otherwise quite diverse texts.

44 On such 'declarative authorship', cf. Love 2002: 45 ("a retrospective bestowal of [...] authorship").

${ }^{45}$ The name $\Lambda$ Alex. 55, Peregrin. 1; furthermore, Lucian is a speaker in the doubted Soloecista) and was connected to the work in paratexts of the manuscript tradition such as scholia or titles (cf. Somnium sive Vita Luciani). Cf. Martelli 2013: 233-234 on the ambivalence inherent to the author's name: "The authorial name, when it appears inside the parameters of a text attributed to the author who holds that name, should function like a signature, making the author 'behind' the work present to the reader, despite his palpable absence. That, at least, is our expectation. Yet in the case of this author's work, the name that identifies its owner/author frequently highlights his disappearance at the same time." 


\section{Bibliography:}

Anderson 1976: G. Anderson, Lucian: Theme and Variation in the Second Sophistic (Leiden, 1976).

Bakhtin 1984: M. Bakhtin, Problems of Dostoevsky's Poetics (Minneapolis, 1984).

Baldwin 1975: B. Baldwin, “The epigrams of Lucian” [in Phoenix 29/4, 1975], pp. 311-335.

Baumbach, von Möllendorff 2017: M. Baumbach, P. von Möllendorff, Ein literarischer Prometheus. Lukian aus Samosata und die Zweite Sophistik (Heidelberg, 2017).

Bompaire 1993: J. Bompaire, Lucien. CEuvres I. Opuscules 1-10 (Paris, 1993). Bracht Branham 1989: R. Bracht Branham, Unruly Eloquence. Lucian and the Comedy of Traditions (Cambridge, MA, London, 1989).

Bretzigheimer 1992: G. Bretzigheimer, "Lukians Dialoge Eikones - Hyper ton eikonon. Ein Beitrag zur Literaturtheorie und Homerkritik", RhM 135/2, 1992, pp. 161-187.

Bruns 1888: I. Bruns, “Lucian's philosophische Satiren”, RhM 43, 1888, pp. 86-103, 161-196.

Dubel 1994: S. Dubel, "Dialogue et autoportrait: les masques de Lucien" [in: Billault, A., coord.: Lucien de Samosate. Actes du colloque international de Lyon organisé au CENTRE D’ÉTUDES ROMAINES ET GALLOROMAINES les 30 septembre-1er octobre 1993, Lyon, 1994], pp. 19-26.

Goldhill 2002: S. Goldhill, Who needs Greek? Conflicts in the cultural history of Hellenism (Cambridge, 2002).

Hafner 2015: M. Hafner, "Lukians Skythendialoge: Fremde Kulturen - fremde Ansichten?" [in Brückmann, G. C. et al., coord.: Cultural Contacts and Cultural Identity, Munich, 2015], pp. 35-44.

Hafner 2017: M. Hafner, Lukians “Apologie”. Eingeleitet, übersetzt und erläutert von Markus Hafner (Tübingen, 2017).

Hafner 2017a: M. Hafner, Lukians Schrift “Das traurige Los der Gelehrten”. Einleitung und Kommentar zu De Mercede Conductis Potentium Familiaribus, lib. 36 (Stuttgart, 2017).

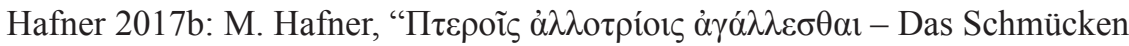
mit fremden Federn als antike Chiffre für literarisches Plagiat" [in A. Guzmán, I. Velázquez, coord.: De vera et falsa historia I, Estudios sobre falsificación documental y literaria antigua. Studies on pseudepigrapha and ancient text forgeries, Madrid, 2017], pp. 283-292. 
Hanson 1998: A. E. Hanson, Galen: "Author and Critic" [in G. Most, coord.: Editing Texts, Texte Edieren, Göttingen, 1998], pp. 22-53.

Harmon, Kilburn, Macleod 1913-1967: A. M. Harmon, K. Kilburn, M. D. Macleod, transl.: Lucian. Works. 8 vols. (Cambridge, MA, London, 19131967).

Hunger 1978: H. Hunger, Die hochsprachliche profane Literatur der Byzantiner (Munich,1978).

Johnson 2010: W. A. Johnson, Readers and Reading Culture in the High Roman Empire: a Study of Elite Communities (Oxford, 2010).

Love 2002: H. Love, Attributing Authorship. An Introduction (Cambridge, 2002).

Macleod 1972-1987: M. D. Macleod, Luciani opera omnia, 4 vols. (Oxford, 1972-1987).

Martelli 2013: F. K. A. Martelli, Ovid's Revisions: The Editor as Author (Cambridge, 2013).

Martínez 2011: J. Martínez, coord.: Fakes and Forgers of Classical Literature - Falsificaciones y falsarios de la Literature Clásica (Madrid, 2011).

McGill 2012: S. McGill, Plagiarism in Latin Literature (Cambridge, 2012).

Mras 1911: K. Mras, Die Überlieferung Lucians (Vienna, 1911).

Mülke 2008: M. Mülke, Der Autor und sein Text. Die Verfälschung des Originals im Urteil antiker Autoren (Berlin, New York, 2008).

Ní Mheallaig 2010: K. Ní Mheallaig, "The game of the name: onymity and the contract of reading in Lucian" [in F. Mestre, P. Gómez Cardó, coord.: Lucian of Samosata: Greek writer and Roman citizen, Barcelona, 2010], pp. 121-132.

Ní Mheallaig 2014: Ní Mheallaig, K., Reading Fiction with Lucian. Fakes, Freakes and Hyperreality (Cambridge, 2014).

Obermeier 1999: A. Obermeier, The History and Anatomy of Auctorial SelfCriticism in the European Middle Ages (Amsterdam et al., 1999).

Peirano 2012: I. Peirano, The Rhetoric of the Roman Fake: Latin Pseudepigrapha in Context (Cambridge, New York, 2012).

Peirano 2012a: I. Peirano, "Authenticity as an Aesthetic Concept: Ancient and Modern Reflections" [in R. Rosen, I. Sluiter, coord.: Aesthetic Value in Classical Antiquity, Leiden, Boston, 2012], pp. 215-242.

Saïd 1993: S. Saïd, "Le «je» de Lucien” [in M.-F. Baslez, P. Hoffman, L. Pernot, coord.: L'invention de l'autobiographie d'Hésiode à Saint Augustin. Actes $d u$ deuxième colloque de l'équipe de recherche sur l'hellénisme postclassique. École normale supérieure, 14-16 juin 1990, Paris, 1993], pp. 253-270.

Scheidegger Lämmle 2016: C. Scheidegger Lämmle, Werkpolitik in der Antike. Studien zu Cicero, Vergil, Horaz und Ovid (Munich, 2016). 
Sidwell 2002: K. Sidwell, "Damning with great praise: paradox in Lucian's Imagines and Pro Imaginibus" [in K. Sidwell, coord.: Pleiades Setting. Essays for Pat Groning on his 65 ${ }^{\text {th }}$ Birthday, Cork, 2002], pp. 107-126.

Sidwell 2009: K. Sidwell, “The Dead Philosopher's Society: New Thoughts on Lucian's Piscator and Eupolis' Demes" [in A. N. Bartley, coord.: A Lucian for our Times, Newcastle, 2009], pp. 109-118.

Speyer 1971: W. Speyer, Die literarische Fälschung im heidnischen und christlichen Altertum: ein Versuch ihrer Deutung (Munich, 1971).

Stemplinger 1912: E. Stemplinger, Das Plagiat in der griechischen Literatur (Leipzig, Berlin, 1912).

Syme 1972: R. Syme, "Fraud and Imposture" [in K. von Fritz, coord.: Pseudepigrapha I. Entretiens sur l'Antiquité Classique 18, VandœuvresGeneva, 1972], pp. 2-21.

von Möllendorff 1995: P. von Möllendorff, Grundlagen einer Ästhetik der alten Komödie. Untersuchungen zu Aristophanes und Michail Bachtin (Tübingen, 1995).

von Möllendorff 2004: P. von Möllendorff, "Puzzling Beauty. Zur ästhetischen Konstruktion von Paideia in Lukians 'Bilder'-Dialogen” [in W. Brandes, H. Leppin, H. Krasser, P. von Möllendorff, coord.: Millenium: Jahrbuch zu Kultur und Geschichte des ersten Jahrtausends n. Chr., vol. 1, Berlin, New York, 2004], pp. 1-24.

Whitmarsh 2001: T. Whitmarsh, Greek Literature and the Roman Empire: the Politics of Imitation (Oxford, 2001).

Whitmarsh 2009: T. Whitmarsh, "Reframing satire: Lucianic metalepsis" [in: M. Cevik, coord.: Uluslararast Samsatl Lucianus Sempozyumu, Adryaman, 2009], pp. 69-75.

Whitmarsh 2011: T. Whitmarsh, Narrative and Identity in the Ancient Greek Novel: Returning Romance (Cambridge, 2011).

Whitmarsh 2013: T. Whitmarsh, An I for an I: reading fictional autobiography [in A. Marmodoro, J. Hill, coord.: The Author's Voice in Classical and Late Antiquity, Oxford, 2013], pp. 233-247.

Whitmarsh 2013a: T. Whitmarsh, Beyond the Second Sophistic: Adventures in Greek Postclassicism (Berkeley, Los Angeles, London 2013).

Ziegler 1950: K. Ziegler, "Plagiat" [in G. Wissowa et al., coord.: Paulys Realenzyklopädie der classischen Antike, 20/2, Stuttgart, 1950], coll. 1956-1979. 
